\title{
Bacterial glycosulphatases and sulphomucin degradation
}

\author{
Anthony M Roberton BSc(Hons) DPhil, Damian P Wright MSc
}

\begin{abstract}
AM Roberton, DP Wright. Bacterial glycosulphatases and sulphomucin degradation. Can J Gastroenterol 1997;11(4):361366. The presence of a high bacterial population in a region of the gastrointestinal tract is usually associated with the secretion of sulphomucins into the mucus gel covering that region. The term 'sulphomucin' is a histochemical description of the staining properties of mucin. At present this term can only be qualitatively related to the percentage of sulphate in the mucin molecule, which makes the term difficult to use in a biochemical and functional sense. Sulphomucins are thought to carry out the normal functions attributed to mucins; in addition, heavy sulphation rate-limits the degradation of mucins by bacterial mucindegrading glycosidases. A number of mucin-specific glycosulphatases have been reported in bacteria, although only two such enzymes have been purified. These enzymes remove part of the sulphate content from sulphomucins and make them more susceptible to further enzymic degradation. The variety of chain locations and sugar attachment sites of sulphate esters on the mucin oligosaccharides, taken together with the data on the enzymes, suggest there will be a spectrum of bacterial glycosulphatases, with different properties, cellular locations and substrate specificities. Bacterial glycosulphatases have the potential to modify sulphated glycoconjugates at mucosal surfaces and should prove useful as biochemical tools for the study of sulphated glycoconjugates.
\end{abstract}

Key Words: Glycosulphatase, Mucin, Sulphomucin

\section{Glycosulfatases bactériennes et dégradation de la sulfomucine}

RÉSUMÉ : La présence d'une forte population bactérienne dans une région du tractus digestif est habituellement associée à la sécrétion de sulfomucines dans le gel muqueux qui tapisse cette région. Le terme sulfomucine est une description histochimique des propriétés colorantes de la mucine. À l'heure actuelle, ce terme ne peut être que qualitativement associé au pourcentage de sulfate présent dans la molécule de mucine, ce qui rend son emploi difficile dans un sens biochimique et fonctionnel. Les sulfomucines accompliraient des fonctions normalement attribuées aux mucines; de plus, de forts taux de sulfatation limitent la dégradation des mucines par les glycosidases responsables de la dégradation de la mucine bactérienne. Un nombre de glycosulfatases spécifiques aux mucines ont été signalés dans les bactéries, bien que peu seulement des ces enzymes aient été purifiées. Ces enzymes éliminent une partie de la teneur en sulfates des sulfomucines et les rendent plus sujettes à la dégradation enzymatique. La variété des localisations des chaînes et des types de fixation aux atomes de sucre des esters de sulfate sur les oligosaccharides de mucine étudiés dans le contexte des données recueillies sur les enzymes donnent à penser qu'il existe un large spectre de glycosulfatases bactériennes dotées de propriétés de localisation cellulaire et de spécificité des substrats différentes. Elles peuvent modifier les glycoconjugués sulfatés sur les surfaces muqueuses et devraient se révéler utiles à titre d'outils biochimiques pour l'étude des glycoconjugués sulfatés.
$\mathrm{T}$ he digestive tract is covered by a viscoelastic mucus gel, in which the main structural molecules are the mucins. These have been categorized historically as neutral mucins, sialomucins or sulphomucins on the basis of the density and types of acidic groups present in their oligosaccharide side chains. However, this categorization, depicted schematically in Figures 1a to 1c, implies a structure that is an over- simplification of the complexity of the molecule. It is more accurate to picture the mucin oligosaccharide chains as containing a mixture of sialic acid and sulphate groups in various ratios (Figure 1d). The terms 'sialomucin', 'sulphomucin' or 'neutral mucin' then more correctly describe the predominance of sialic acid or sulphate acidic groups or their scarcity in the mucin molecule. Recent analyses of oligosaccharide

This paper was part of a symposium entitled "Selected topics in pediatric gastroenterology and nutrition" held in October 1995 to honour the academic career of Dr Gordon G Forstner

School of Biological Sciences, University of Auckland, Auckland, New Zealand

Correspondence: Dr AM Roberton, School of Biological Sciences, University of Auckland, Private Bag 92019, Auckland, New Zealand. Telephone 64-9-373-7599 ext 8233, fax 64-9-373-7414 


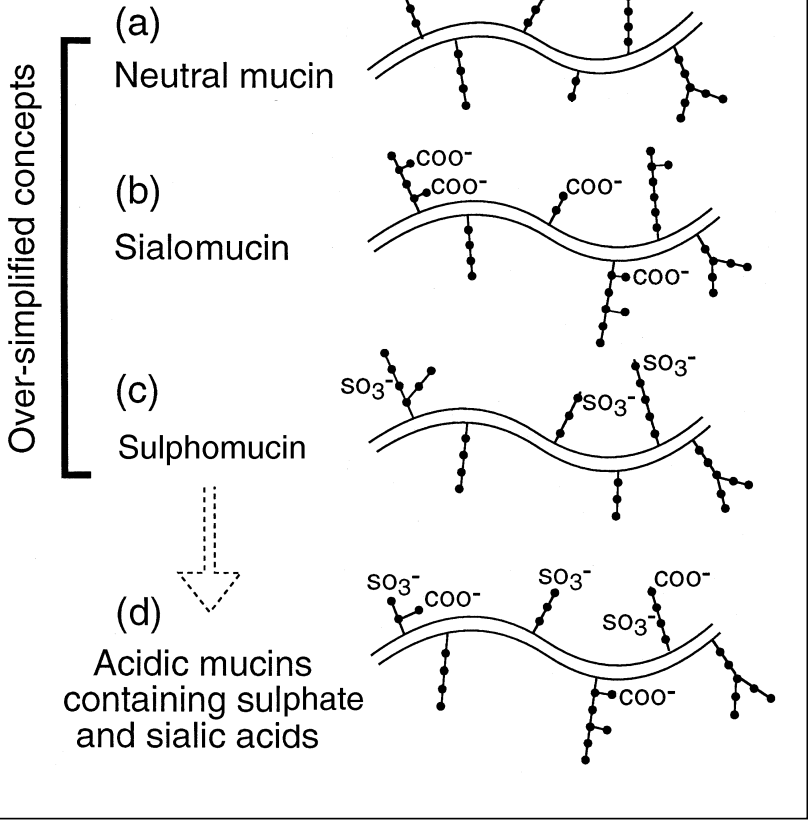

Figure 1) Classes of mucins. Stylized diagrams of (a) neutral mucin chain, (b) sialomucin chain and (c) sulphomucin chain. These concepts are oversimplified because they show only one type of acidic group within the mucin. A more realistic concept of an acidic mucin chain containing both sulphate and sialic acid groups within the molecule is shown in (d)

TABLE 1

Sulphate contents of human salivary and intestinal mucins

\begin{tabular}{lcc}
\hline Mucin & $\begin{array}{c}\text { Sulphate } \\
\text { content }^{*}\end{array}$ & Reference \\
\hline $\begin{array}{l}\text { Saliva (submandibular-sublingual, high } \\
\quad \text { molecular weight mucin, MG1) }\end{array}$ & 7.0 & 5 \\
Small intestine & 0.45 & 6 \\
& 1.6 & 7 \\
Ileum (ileal conduit) & 1.2 & 8 \\
Colon (cystic fibrosis patient) & 2.0 & 9 \\
Colon (isolated sulphomucin fraction) & 6.5 & 10 \\
\hline
\end{tabular}

*Grams sulphate/100 g mucin

chain structures have shown that both sulphate and sialic acid groups can be present within a single oligosaccharide chain $(1,2)$.

\section{SULPHOMUCINS}

In humans the mouth and the colon are the two main regions of the digestive tract containing sulphomucins. As a general rule, the areas of digestive tract that are the habitat of large numbers of microorganisms are also rich in secreted sulphomucins, suggesting that these two phenomena have become linked during evolution. The converse is not true because there are other areas that secrete sulphomucins but do not have a large bacterial population, such as the submucosal esophageal glands and the pancreaticobiliary epithe- lium. Sulphomucins can be visualized in mucin-secreting cells and the overlying mucus layer by staining with high iron diamine (HID) at $\mathrm{pH} 1.5$, Alcian blue at $\mathrm{pH}$ 1.0, or HID and Alcian blue at $\mathrm{pH} 2.5$ (3). When colon tissue is treated with the last of these techniques, the sulphomucins in the crypt goblet cells stain dark brown with HID, while the sialomucins, containing mucin with less sulphate and larger amounts of sialic acid, stain blue with Alcian blue.

There is some difficulty in using the term sulphomucin in a biochemical context. The term was coined by histochemists to describe mucins that stain with HID or Alcian blue at $\mathrm{pH} 1$. However, while this characterization broadly relates to the name, the percentage of sulphate in mucin (ie, grams of sulphate $/ 100 \mathrm{~g}$ mucin) needed to give a positive stain is unknown (4). Table $1(5-10)$ shows the sulphate content of a selection of isolated human mucins from saliva and intestines. The small intestinal mucins would presumably be classified histochemically as sialomucins rather than sulphomucins, and the unfractionated colonic mucin (9) would be a mixture of sialomucins and sulphomucins. It is clear that small intestinal mucins (sialomucins) contain sulphate, although in lesser amounts than colonic mucin. The quantity of sulphate needed to qualify a mucin for categorization as a sulphomucin is unclear. Perhaps the borderline should not be defined until the properties that sulphate imparts to a mucin are better understood, and until it is known whether all sulphate groups should be considered equivalent despite different chain locations and sugar attachment sites. So there is a problem in defining boundaries within which to define the term sulphomucin.

\section{ROLES OF SULPHOMUCINS}

What are the sulphomucins doing in the digestive tract? Presumably they possess many of the functions of all mucins, including participating in the barrier role and protecting the underlying surface from the aggressive and damaging luminal factors in the particular region. They also lubricate the mucosal surface, preventing abrasion by food or fecal particles during passage through the tract. They are part of the unstirred water layer through which all substances must diffuse to enter or leave the epithelial cell surface during absorption and secretion. Mucins are the main structural molecules of the visco-elastic mucus gel, and their reduced viscosity and calcium binding activity both increase with sulphate content, although the values are also affected by forming complexes with other components of the mucin layer (11). Sulphomucins may be a target for certain bacterial receptors. In addition, there is accumulating evidence that sulphomucins rate-limit mucin degradation by mucin-degrading bacterial enzymes. The evidence for the last of these roles is summarized below.

\section{EVIDENCE THAT SULPHOMUCINS RATE-LIMIT MUCIN DEGRADATION BY BACTERIAL ENZYMES} The first line of evidence comes from the general rule that, under normal conditions, the presence of a large bacterial population in a region of an animal digestive tract coincides 
with the presence of sulphomucins. This is teleological evidence that the two have evolved together, and the latter may be necessary to control the former.

Second, evidence that sulphated glycopeptides inhibit certain enzymes is provided by the studies of Mian et al (12). They demonstrated that sulphated glycopeptides inhibit Clostridium perfringens neuraminidase activity, particularly when larger molecular weight neuraminidase substrates were used in the assay. The sulphated glycopeptides probably inhibit by steric hindrance.

Third, when a colonic Prevotella species isolate (formerly classified as Bacteroides species) was grown on pig colonic and pig gastric mucin, the heavily sulphated colonic mucin was less degraded than the more lightly sulphated gastric mucin (13). Two other mucin-degrading colonic isolates (one Clostridium species and a Bacteroides species) were also studied. Not only did both isolates remove less sulphate from the pig gastric mucin than the Prevotella species isolate, but they also removed less carbohydrate from the mucin. These results are consistent with the concept that sulphate removal is limiting the carbohydrate removal.

Fourth, results from a study of the mucin composition of sputum in patients with and without Pseudomonas aeruginosa infection of the lungs showed that when sputum was infected, the neutral mucin component was extensively and selectively degraded compared with the sulphomucin component (14). This resulted in a relative increase in the sulphomucin content.

Next, Tsai and co-workers (15) studied the degradation of colonic mucin by various fractions from the supernatant fluid of feces, which contains a mixture of colonic bacterial enzymes. Addition of a sulphatase-containing fraction to a glycosidase-containing fraction increased the $\left[{ }^{3} \mathrm{H}\right]$ sugar release from $\left[{ }^{3} \mathrm{H}\right]$ glucosamine-labelled mucin fivefold. The removal of some sulphate from the mucin must expose formerly inaccessible carbohydrate to the action of glycosidases.

Sixth, two research groups have reported that fecal enzyme extracts from ulcerative colitis patients have higher glycosulphatase activities than those from controls $(16,17)$. Fecal enzyme extracts from ulcerative colitis patients degrade normal colonic mucin more efficiently and extensively than extracts from control patients, correlating with the higher glycosulphatase levels (16). Patients with ulcerative colitis also have mucin with a lower sulphate content in the affected area than controls, and mucin from the former is more easily degraded by fecal enzyme extracts than mucin from the latter (16), again correlating with lower sulphate content in the mucin.

Taken together, the evidence above suggests indirectly that the presence of high levels of sulphate in a mucin decreases its susceptibility to bacterial glycosidases, limiting the rate and extent of the degradation. Also, mucin-specific glycosulphatases increase the susceptibility of a mucin to glycosidase activities.

There is good biochemical evidence that $\mathrm{O}$-acetylation of sialic acids, the other acidic residues present in mucins,
TABLE 2

Sulphated sugars in mucins

\begin{tabular}{lcc}
\hline Sulphated sugar & Origin & Reference \\
\hline $\begin{array}{c}\text { N-acetylglucosamine- } \\
\text { 6-sulphate }\end{array}$ & Pig stomach & 18 \\
Rat stomach & 19 \\
$\begin{array}{c}\text { N-acetyglucosamine- } \\
\text { 3- or -4-sulphate }\end{array}$ & Dog submaxillary & $1,2,20,21$ \\
$\begin{array}{c}\text { N-acetyglucosamine- } \\
\text { bis-sulphate }\end{array}$ & Rat stomach & 22 \\
Galactose-6-sulphate & Rat stomach & 19 \\
Galactose-4-sulphate & $\begin{array}{c}\text { Human tracheobronchial } \\
\text { Galactose-3-sulphate }\end{array}$ & $1,20,21,23$ \\
\hline
\end{tabular}

makes them less easily removable from oligosaccharide chains by the action of many sialidases. Thus O-acetylation of sialic acids have been considered to protect mucin chains from degradation by bacterial enzymes. However, some $9 \%$ of the Caucasian population is homozygous for an inactive O-acetyl transferase gene (OAT-/OAT $\left.{ }^{-}\right)$and these individuals secrete sialic acids lacking O-acetyl substituents (3). The question then arises whether the increased neuraminidase sensitivity predisposes such individuals to colorectal diseases, but there is no strong evidence that they have any differences in disease susceptibility (3).

\section{SULPHATED SUGAR STRUCTURES}

Analyses of sulphated oligosaccharides from mucins show that sulphate is esterified to sugars in a variety of ways (Table 2 [18-24]). These structures need to be emphasized in studies of mucin degradation because they represent the substrate specificities that bacterial enzymes have to cleave in order to degrade sulphomucins. The predominant sulphated sugars present in human mucins are $\mathrm{N}$-acetylglucosamine-6-sulphate, galactose-6-sulphate, galactose-3-sulphate and perhaps gahlactose-4-sulphate. It may also be important whether the sulphated sugars are at the nonreducing terminus of the chain or within the chain. Sulphated sugars at the nonreducing terminus will block the action of exoglycosidases. This will only become apparent when a variety of different mucin-specific glycosulphatases become available for study. At present there is little information on which sulphated sugars are present in colonic mucins. This information will be pertinent when interpreting the apparent resistance of colonic mucin to bacterial degradation.

\section{HID STAINING}

As a step towards understanding the relationship between the sulphate content of mucin molecules and the term sulphomucin as used in histochemistry, we have studied the HID staining of isolated mucins (unpublished data). The mucins were purified by gel chromatography followed by gradient centrifugation in cesium chloride. Aliquots of purified mucin were slot blotted on nitrocellulose membranes, stained with HID at $\mathrm{pH} 1.5$ and quantified by image scan- 


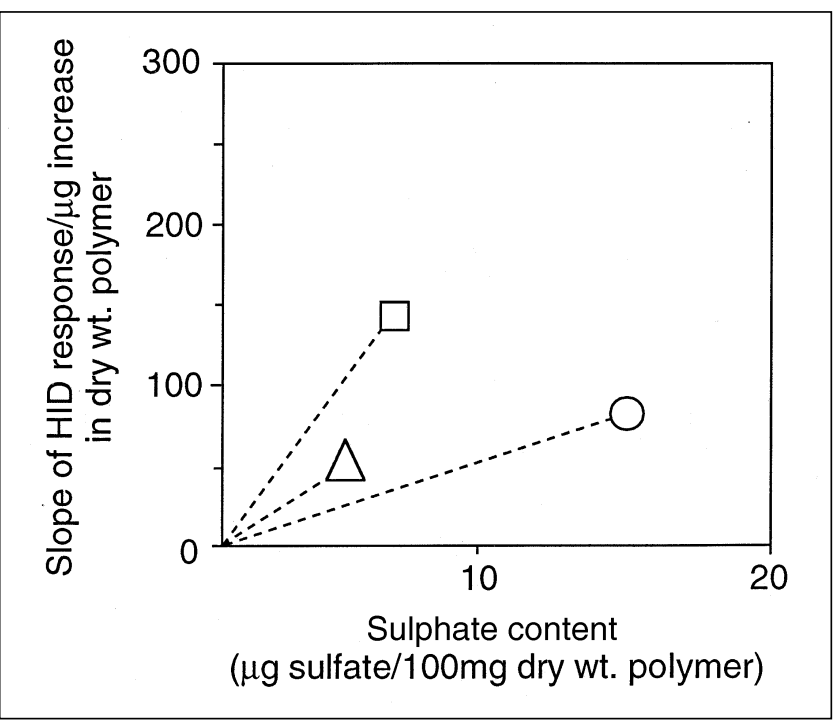

Figure 2) The slope of high iron diamine (HID) staining response versus the sulphate content of sulphated polymers. $\square$ Pig stomach fundic mucin (cesium chloride gradient purified); $\Delta$ Pig stomach antral mucin (cesium chloride gradient purified); OChondroitin sulphate. Sulphate was measured by the barium rhodizonate method (25)

ning. The relationships of the intensity of the HID stain response versus the dry weight of sulphated mucin or chondroitin sulphate (used as a standard) added were not initially linear (data not shown). However, at between 2 and $8 \mu \mathrm{g}$ dry weight the responses were sufficiently linear to measure the slopes. These data were further analyzed by plotting the HID response versus the sulphate content (Figure 2 [25]). There was no correlation between the sulphate content and the HID stain intensity. However, with respect to the two mucins (pig stomach antral and fundic mucins), there was a more than proportional increase in stain intensity with increasing sulphate content.

In other experiments (unpublished data) pig stomach fundic mucin was pretreated with a purified mucin-specific glycosulphatase (26), which removes sulphate from $\mathrm{N}$ acetylglucosamine-6-sulphate, before slot blotting. The mucin sulphate content decreased by $23 \%$, from $6.2 \%$ to $4.6 \%$ sulphate, while the HID stain decreased $47 \%$, again showing that the HID staining was significantly more than proportional to the sulphate content. As expected, experiments in which the sialic acids were removed by potassium hydroxide followed by neuraminidase treatment (27) gave no decrease in HID staining.

It was concluded that the basophilic HID stain colour response is more complicated than simply a measure of sulphate present in the mucin, ie, it provides a qualitative rather than quantitative measure of mucin sulphation. So the term sulphomucin is a relatively inexact biochemical term which nevertheless is useful descriptively.

\section{MUCIN-SPECIFIC GLYCOSULPHATASES}

A number of mucin-specific glycosulphatases that remove sulphate from sulphomucins have recently been discovered in gastrointestinal tract bacteria (Table 3 [28-32]). These include bacteria from the mouth, stomach and colon. Because these glycosulphatases have the potential to modify the sulphated glycoconjugates at the mucosal surface and to increase the rate at which bacterial glycosidases can degrade the major component of the mucus layer, studies of their distribution among bacteria, substrate specificity, cellular or extracellular location, and molecular properties are needed to understand their role(s). It is important to ensure that the enzymes studied are mucin-specific because many other sulphated molecules in the digestive tract are degraded by different sulphatases.

Most research on mucin-specific glycosulphatases has reported their existence in particular bacteria (29-32) or glycosulphatase activity in contents of the respiratory or digestive tract $(14,15)$. Two enzymes have been purified to homogeneity. A mucin-specific glycosulphatase, produced by one or more unknown bacteria, has been purified from fecal fluid (15). It is thought to be a secreted enzyme and has a molecular weight of $15 \mathrm{kDa}$ and a $\mathrm{pH}$ optimum of 4.5. A mucinspecific glycosulphatase with very different properties has been isolated from Prevotella species strain RS2. This enzyme is a homodimer with subunits of $58 \mathrm{kDa}$, is periplasmic and has a $\mathrm{pH}$ optimum of 7.4. Its location in the periplasm is con-

TABLE 3

Mucin-specific glycosulphatases

\begin{tabular}{|c|c|c|c|c|}
\hline Organism & Substrate specificity & Location & pH optimum & Reference \\
\hline \multirow[t]{2}{*}{ Prevotella species strain RS2 } & $\begin{array}{l}\text { Glucose-6-sulphate } \\
\mathrm{N} \text {-acetylglucosamine-6-sulphate } \\
{\left[{ }^{35} \mathrm{~S}\right] \text { rat gastric mucin }}\end{array}$ & Periplasm & 7.4 & 26,28 \\
\hline & Galactose-6-sulphate & Cytoplasm & 7.0 & 26 \\
\hline Bacteroides thetaiotaomicron & Glucose-6-sulphate & Culture supernatant & 5.0 & 29 \\
\hline Human feces & $\begin{array}{l}\text { Glucose-6-sulphate } \\
{\left[{ }^{35} \mathrm{~S}\right] \text { human colonic mucin }}\end{array}$ & Fecal supernatant & 4.5 & 15 \\
\hline $\begin{array}{l}\text { Ruminococcus torques IX-70 } \\
\text { Bifidobacterium VIII-210 }\end{array}$ & $\beta$-galactose-6-sulphate-(1-4)-glucitol & Culture supernatant & 5.0 & 30 \\
\hline Helicobacter pylori & {$\left[{ }^{35} \mathrm{~S}\right]$ human gastric mucin } & Culture supernatant & 5.7 & 31 \\
\hline $\begin{array}{l}\text { Streptococcus mitis } \\
\text { Streptococcus salivarius } \\
\text { Streptococcus mutants }\end{array}$ & {$\left[{ }^{35} \mathrm{~S}\right]$ human colonic mucin } & Freeze-dried cells & - & 32 \\
\hline
\end{tabular}


sistent with results from studies on the degradation of several polysaccharides by Gram-negative Bacteroides. In these colon anaerobes, macromolecules are first bound to the cell surface, then degraded by periplasmic enzymes (33), thus preventing access by competing bacteria to nutritious products. Another mucin-specific glycosulphatase, with specificity for galactose-6-sulphate, is present in Prevotella (26). This second enzyme may account for the observation that the purified glycosulphatase ( $\mathrm{N}$-acetylglucosamine-6-sulphatase) can only remove $33 \%$ of sulphate from [ $\left.{ }^{35} \mathrm{~S}\right]$-labelled rat gastric mucin (26), but crude cell extracts of Prevotella can remove $79 \%$ of the sulphate (unpublished data).

\section{FUTURE DIRECTIONS}

A systematic study of a spectrum of representative mucinspecific glycosulphatases is clearly required to gain a perspective of this family of enzymes; and the relationship of the different glycosulphatases to each other and to other proteins needs to be clarified by genetic characterization. Results will prove useful in assessing the extent to which the mucus barrier depends on sulphation to maintain the steady state between destruction by bacterial (and host) digestive enzymes and the rate of resynthesis and secretion.

The relationship of glycosulphatases to several disease situations deserves further examination. The presence of mucin-specific glycosulphatases in several oral streptococci

ACKNOWLEDGEMENTS: The financial support of the New Zealand Lottery Health Research Committee is gratefully acknowledged.

\section{REFERENCES}

1. Mawhinney TP, Landrum DC, Gayer DA, Barbero GJ. Sulfated sialo-oligosaccharides derived from tracheobronchial mucous glycoproteins of a patient suffering from cystic fibrosis. Carbohydr Res 1992;235:179-97.

2. Lo-Guidice J-M, Wieruszeski J-M, Lemoine J, Verbert A, Roussel P, Lamblin G. Sialylation and sulfation of the carbohydrate chains in respiratory mucins from a patient with cystic fibrosis. J Biol Chem 1994;269:18794-813.

3. Jass JR, Roberton AM. Colorectal mucin histochemistry in health and disease: a critical review. Pathol Int 1994;44:487-504.

4. Allen A, Hoskins LC. Colonic mucins in health and disease. In: Kirsner R, Shorter RG, eds. Diseases of the Colon and Rectum. Baltimore: Williams \& Wilkins, 1988:65-94.

5. Levine MJ, Reddy MS, Tabak LA, et al. Structural aspects of salivary glycoproteins. J Dent Res 1987;66:436-41.

6. Wesley A, Forstner JF, Forstner GG. Structure of intestinal-mucus glycoprotein from human post-mortem or surgical tissue: inferences from correlation analysis of sugar and sulfate composition of individual mucins. Carbohydr Res 1983;115:151-63.

7. Mantle M, Allen A. Gastrointestinal mucins. In: Davison JS, ed. Gastrointestinal Secretions. London: Wright, 1989:202-29.

8. Roberton AM, Rabel B, Harding CA, Tasman-Jones C, Harris PJ, Lee SP. Use of the ileal conduit as a model for studying human small intestinal mucus glycoprotein secretion. Am J Physiol 1991;261:G728-34.

9. Podolsky DK, Isselbacher KJ. Composition of human colonic mucin. Selective alterations in inflammmatory bowel disease. J Clin Invest 1983;72:142-53.

10. Irimura $T$, Wynn DM, Hager LG, Cleary KR, Ota DM. Human colonic sulfomucin identified by a specific monoclonal antibody. Cancer Res 1991;51:5728-35. suggests that it may modify the sulphation level of mucins during formation of dental plaque (32). The observation that fecal mucin-specific glycosulphatases are elevated in ulcerative colitis while the level of sulphation of mucins is decreased indicates that the changes either are secondary to the disease process or contribute to the disease by upsetting the function of the mucus barrier (17). The finding that binding of Helicobacter pylori to the sulphated glycolipids of host cells is inhibited by sulphomucin suggests that sulphomucins may, in certain situations, have a role in 'distracting' colonizing bacteria from finding receptors present on the host cell surface.

Glycosulphatases, when they become available, are likely to become useful biochemical tools. Their future use can be envisaged in the technology of oligosaccharide sequencing, involving sequential removal of nonreducing sugars by glycosidases. They may prove useful in studies on the structure of sulphated sugars in oligosaccharides from glycoproteins and perhaps glycolipids. They also have the potential to desulphate sulphomucins, which could then be used for studies on the effect of sulphation on mucin degradability, rheology, permeability and gel forming capacity. Glycosulphatases with a suitable specificity may also become useful tools in studies on cell-cell adhesion because sulphated oligosaccharides have recently been shown to be the preferred targets of E- and L-selectins $(34,35)$.
11. Mian N, Kent PW. Role of directional $\mathrm{Ca}^{2+}$ effect on reduced viscosities of mucus secretions from chicken trachea in vitro. Biochem Biophys Acta 1986;883:486-95.

12. Mian N, Anderson CE, Kent PW. Neuraminidase inhibition by chemically sulphated glycopeptides. Biochem J 1979;181:377-85.

13. Stanley RA, Ram SP, Wilkinson RK, Roberton AM. Degradation of pig gastric and colonic mucins by bacteria isolated from the pig colon. Appl Environ Microbiol 1986;51:1104-9.

14. Houdret N, Ramphal R, Scharfman A, et al. Evidence for the in vivo degradation of human respiratory mucins during Pseudomonas aeruginosa infection. Biochim Biophys Acta 1989;992:96-105.

15. Tsai HH, Sunderland D, Gibson GR, Hart CA, Rhodes JM. A novel mucin sulphatase from human faeces: its identification, purification and characterisation. Clin Sci 1992;82:447-54.

16. Corfield AP, Wagner SA, O'Donnell LJD, Durdy P, Mountford RA, Clamp JR. The roles of enteric bacterial sialidase, sialate $\mathrm{O}$-acetyl esterase, and glycosulfatase in the degradation of human colonic mucin. Glycoconj J 1993;10:72-81.

17. Tsai HH, Dwarakanath AD, Hart CA, Milton JD, Rhodes JM. Increased faecal mucin sulphatase in ulcerative colitis: a potential target for treatment. Gut 1995;36:570-6.

18. Slomiany BL, Meyer K. Isolation and structural studies of sulfated glyoproteins of hog gastric mucosa. J Biol Chem 1972;247:5062-70.

19. Liau YH, Horowitz MI. Incorporation in vitro of $\left[{ }^{3} \mathrm{H}\right]$ glucosamine or $\left[{ }^{3} \mathrm{H}\right]$ glucose and $\left[{ }^{35} \mathrm{~S}_{\mathrm{SO}_{4}}{ }^{2-}\right.$ into rat gastric mucosa. J Biol Chem 1982;257:4709-18.

20. Mawhinney TP, Adelstein E, Gayer DA, Landrum DC, Barbero GJ. Structural analysis of monosulfated side-chain oligosaccharides isolated from human tracheobronchial mucous glycoproteins. Carbohydr Res 1992;223:187-207.

21. Sangadala S, Bhat UR, Mendicino J. Structures of sulfated oligosaccharides in human trachea mucin glycoproteins. Mol Cell Biochem 1993; 126:37-47.

22. Lombard CG, Winzler RJ. Isolation and characterisation of oligosaccharides from canine submaxillary mucin. Eur J Biochem 1974;49:77-86. 
23. Mawhinney TP, Adelstein E, Morris DA, Mawhinney AM, Barbero GJ. Structure determination of five sulfated oligosaccharides derived from tracheobronchial mucus glycoproteins. J Biol Chem 1987;262:2994-3001.

24. Lamblin G, Rahmoune H, Wieruszeski J-M, Lhermitte M, Strecker G, Roussel P. Structure of two sulphated oligosaccharides from respiratory mucins of a patient suffering from cystic fibrosis. A fast atom bombardment m.s. and ${ }^{1} \mathrm{H}$-n.m.r. spectrscopic study. Biochem J 1991;275:199-206.

25. Silvestri LJ, Hurst RE, Simpson L, Settine JM. Analysis of sulphate in complex carbohydrates. Anal Biochem 1982;123:303-9.

26. Roberton AM, McKenzie C, Scharfe N, Stubbs L. A glycosulphatase that removes sulphate from mucus glycoprotein. Biochem J 1993;293:683-9.

27. Culling CFA, Reid PE, Clay MG, Dunn WL. The histochemical demonstration of $\mathrm{O}$-acetylated sialic acid in gastrointestinal mucins. Their association with the potassium hydroxide-periodic acid-Schiff effect. J Histochem Cytochem 1974;22:826-31.

28. Wilkinson RK, Roberton AM. A novel glycosulphatase isolated from a mucus glycopeptide-degrading Bacteroides sp. FEMS Microbiol Lett 1988;50:195-9.

29. Tsai HH, Hart CA, Rhodes JM. Production of mucin degrading sulphatase and glycosidases by Bacteroides thetaiotaomicron. Lett Appl Microbiol 1991;13:97-101.
30. Corfield AP, Wagner SA, Clamp JR, Kriaris MS, Hoskins LC. Mucin degradation in the human colon: production of sialidase, sialate $\mathrm{O}$-acetylase, $\mathrm{N}$-acetylneuraminate lyase, arylesterase, and glycosulfatase activities by strains of faecal bacteria. Infect Immun 1992;60:3971-8.

31. Murty VLN, Piotrowski J, Morita M, Slomiany A, Slomiany BL. Inhibition of Helicobacter pylori glycosulfatase activity toward gastric sulfomucin by nitecapone. Biochem Int 1992;26:1091-9.

32. Smalley JW, Dwarakanath AD, Rhodes JM, Hart CA. Mucin-sulphatase activity of some oral streptococci. Caries Res 1994;28:416-20.

33. Salyers AA, Valentine P, Hwa V. Genetics of polysaccharide utilisation pathways of colonic Bacteroides species. In: Sebald M, ed. Genetics and Molecular Biology of Anaerobic Bacteria. Brock/Springer Series in Contemporary Bioscience. New York: Springer-Verlag, 1993:505-16.

34. Yuen C-T, Bezouska K, O'Brien J, et al. Sulfated blood group Lewis ${ }^{\mathrm{a}}$ a superior oligosaccharide ligand for human E-selectin. J Biol Chem 1994:269:1595-8.

35. Green PJ, Yuen C-T, Childs RA, et al. Further studies of the binding specificity of the leukocyte adhesion molecule, L-selectin, towards sulphated oligosaccharides - suggestion of a link between the selectinand the integrin-mediated lymphocyte adhesion systems. Glycobiology 1995;5:29-38. 


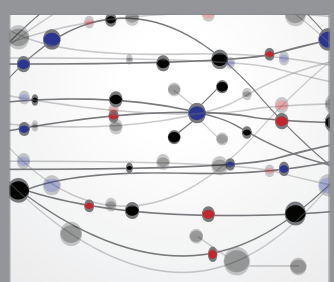

The Scientific World Journal
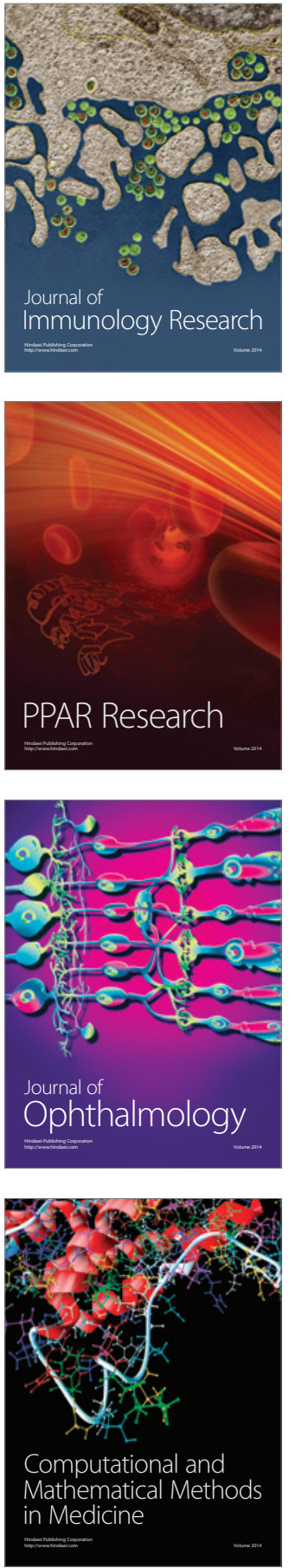

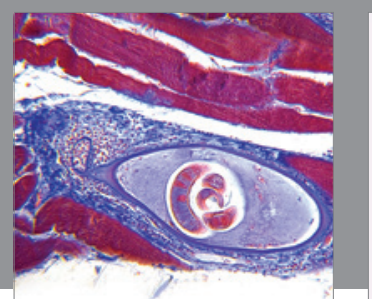

Gastroenterology Research and Practice

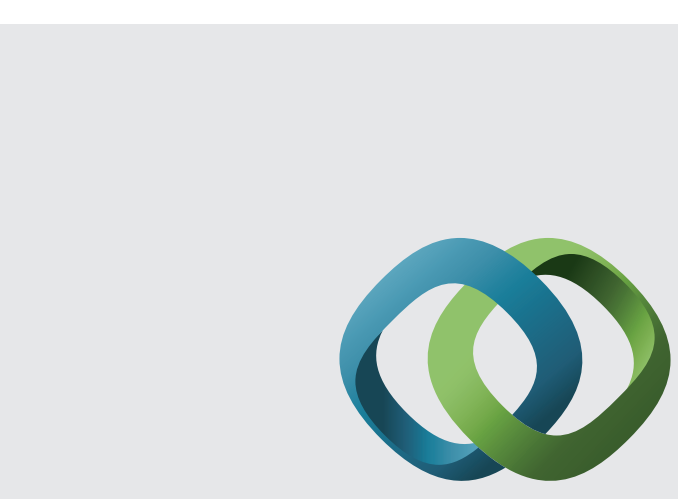

\section{Hindawi}

Submit your manuscripts at

http://www.hindawi.com
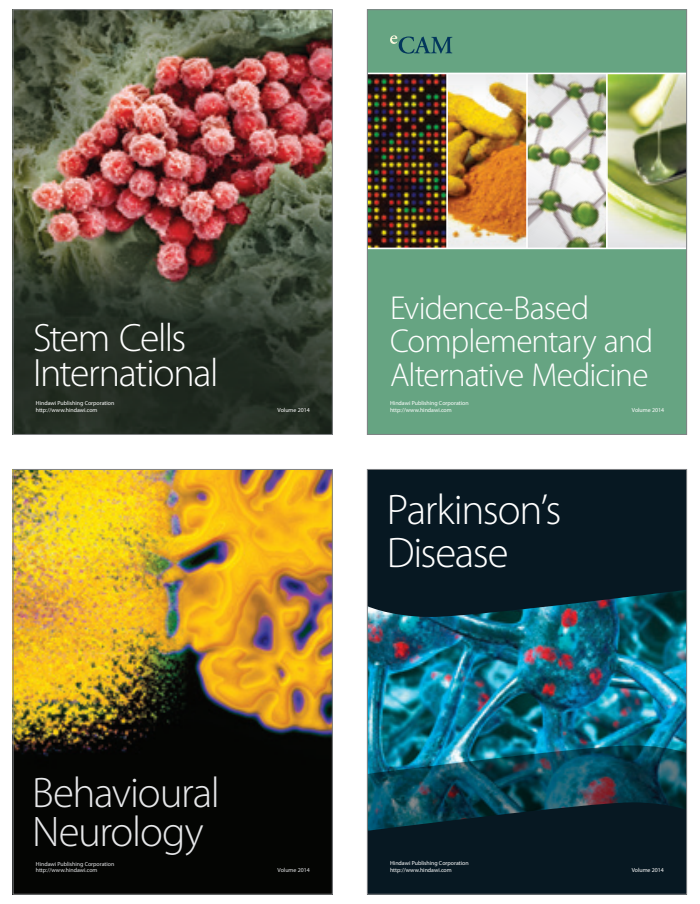
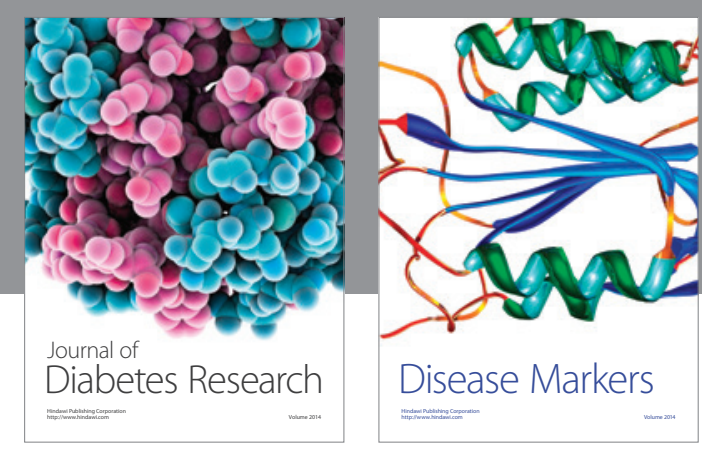

Disease Markers
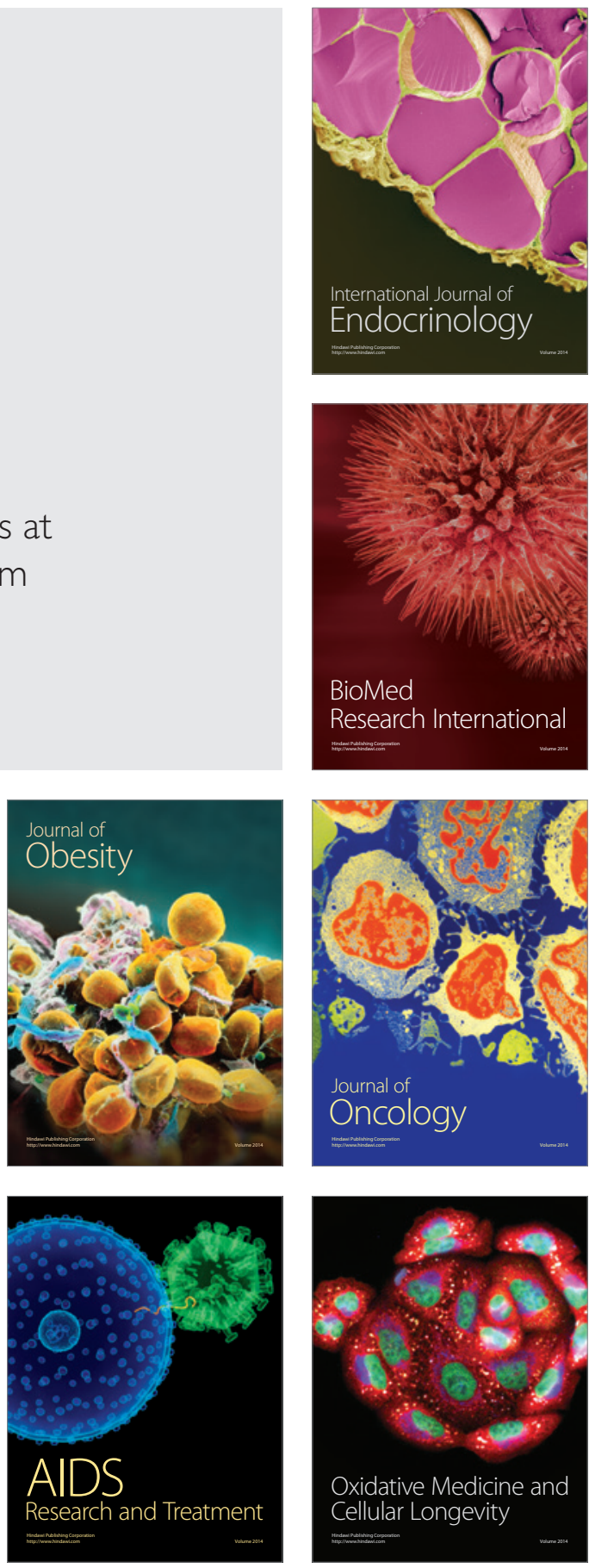